\title{
Neural network unsupervised classification as an advanced presalt reservoir characterization technique: a Buzios Field case study
}

Danilo Jotta Ariza Ferreira ${ }^{1,2}$, Wagner Moreira Lupinacci ${ }^{1}$, Thais Mallet de Castro ${ }^{1}$, Nathalia Ladeira Casado ${ }^{1,2}$, Marcelo Alvarenga $^{2}$, Yuri Bezerra ${ }^{2}$, José Fernando Caparica Junior ${ }^{2}$, Marco Antonio Cetale Santos ${ }^{1}$

Universidade Federal Fluminense ${ }^{1}$

Schlumberger ${ }^{2}$

Copyright 2019, SBGf - Sociedade Brasileira de Geofísica

This paper was prepared for presentation during the $16^{\text {th }}$ International Congress of the Brazilian Geophysical Society held in Rio de Janeiro, Brazil, 19-22 August 2019.

Contents of this paper were reviewed by the Technical Committee of the $16^{\text {th }}$ International Congress of the Brazilian Geophysical Society and do not necessarily Inernational congres of the Brazilian Geophysical Society and represent any position of the SBG, its officers or members. Electronic reproduction or storage of any part of this paper for commercial purposes without the written consen of the Brazilian Geophysical Society is prohibited.

\section{Abstract}

This paper proposes the use of unsupervised neural network classification using multiple seismic attributes as a methodology for advanced reservoir characterization applied the pre-salt Barra Velha Formation carbonate reservoirs in the central portion of the Buzios Field, Santos Basin. The need of this advanced approach is to the fact that these reservoirs are known to be very complex due to its high level of heterogeneity and anisotropy, that affects directly its porosity and permeability. The acoustic impedance, rms amplitude and variance attributes were used for the unsupervised seismic facies classification. Coupled analysis of amplitude seismic features and the classification results allowed the differentiation of two seismic patterns within the study area: aggradational/ progradational carbonate platforms and build-ups. Potential areas for drilling new wells were identified in the eastern part of the field from the seismic facies probability occurrence and zonation maps.

\section{Introduction}

The pre-salt reservoirs in the Santos Basin are one of the most challenging targets for the exploration and production of oil and gas, due to their geological heterogeneity and anisotropy requiring the deep understanding of depositional and post-depositional processes coupled with advanced reservoir characterization techniques for precise positioning of wells (Bruhn et al., 2017).

Seismic facies associated to these reservoirs during the sag and upper rift phases, comprised in the Barra Velha formation, are represented mainly by buildups, aggradational or progradational carbonate platforms, and debris (Wright, 2012; Buckley et al., 2015; Kattah and Balabekov, 2015; Saller et al., 2016; Jesus et al., 2019; Ferreira et al., 2019).

Facies associated with these seismic features are comprised, predominantly, of stromatolites/shrubs, grainstones, spherulitic packstones and pelagic carbonates (Terra et al., 2010; Boyd et al., 2015; Muniz and Bosence, 2015; Rezende and Pope, 2015), eventually intercalated with subaerial basaltic lava flow units with high evidence of hydrothermal fluid percolation in a lacustrine environment (Szatmari and Milani, 2016; Fornero et al., 2018).

One of the most promising advanced approaches for seismic facies characterization of the Barra Velha Formation carbonate reservoirs is the unsupervised facies classification using neural network algorithms coupled with the used of stratigraphic and structural attributes, as described in the works of Johann et al. (2012), Jesus et al. (2019) and Ferreira et al. (2019).

We propose the use of multiple seismic attributes in an unsupervised neural network algorithm for seismic facies classification of the Barra Velha Formation within an area of the Buzios Field, Santos Basin, in order to better characterize the reservoir and to determine new areas for drilling (Figure 1).

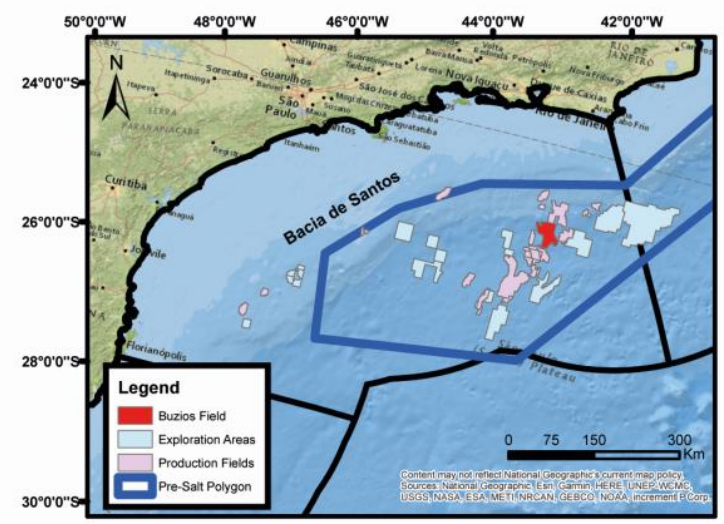

Figure 1: Location of Buzios field in Santos basin.

\section{Methodology}

The dataset available consisted in approximately $770 \mathrm{~km}^{2}$ of 3D post-stack depth migrated seismic (PSDM) and migration-velocity model, and 16 wells located in southern part of the Buzios Field. All the data as well as the seismic lines represented in this study are shown in Figure 2.

The base of the salt (upper Aptian age), Pre-Alagoas (lower Aptian age) and the top of the basement unconformities as well as the faults of the rift and sag phases were interpreted according to the concepts of 
seismic stratigraphic reflector terminations, as described in Brown Jr. and Fisher (1977) and Della Fávera (2001). The map of the base of the salt is shown in Figure 2 and an seismic line, with the basement, Pre-Alagoas and base of the salt unconformities and the faults interpreted, is shown in Figure 3.

The interest interval for the seismic facies classification is comprised between the Pre-Alagoas and base of the salt unconformities and represent, respectively, the base and top of the Barra Velha Formation (Moreira et al., 2007). Seismic patterns present in this interval were also identified and analyzed and allowed to build an initial geological model and assisted the interpretation of seismic facies obtained from neural network classification.

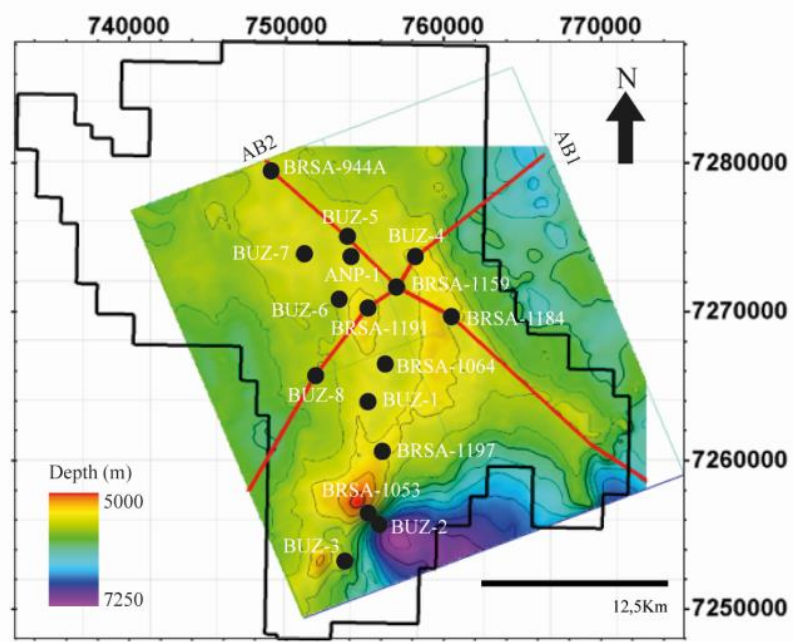

Figure 2: Dataset available in the Buzios Field (black polygon) area including the wells (black circles) and 3D seismic (green square). Also, the arbitrary seismic lines represented in the study are highlighted as red lines. a structural smoothing filter (Hale, 2009) to reduce the influence of structurally oriented noise.

The response of several attributes extracted based on amplitude, phase and frequency of preconditioned seismic data need to be analyzed for identification of stratigraphic and structural characteristics that could individualize the seismic patterns in the area, as proposed by Ferreira et al. (2019) and Jesus et al. (2019).

Three seismic attributes were chosen as input for unsupervised classification: the acoustic impedance obtained using the inversion algorithm described by Barclay et al. (2008), Dai et al. (2011) and Basha et al. 2012), rms amplitude extracted using the method proposed by Taner et al. (1979), and variance calculated using the approach created by Bemmel and Pepper (2000). The stratigraphic and structural characteristics highlighted by the attributes related to the seismic patterns were also discriminated.

Neural network technique was developed by McCulloch and Pitts (1943) based on the brain learning process through interaction amongst neurons when given a stimulus. We used a multi-layered perceptron network with lateral connections for inhibition architecture and competitive learning method (Russell and Norvig, 2010; Du and Swamy, 2014) for unsupervised discrimination of five seismic facies. The ideal number of facies was defined after a series of trial and error attempts ranging from 3 to 10 facies.

Finally, the seismic facies classification volume was further analyzed for a better geological understanding of seismic patterns distribution. In addition, it was used to build probability occurrence and zonation maps for the seismic patterns in the study area, considering average facies quantity for the target interval.

Prior to the generation of the seismic attributes used for classification, the seismic data was preconditioned using

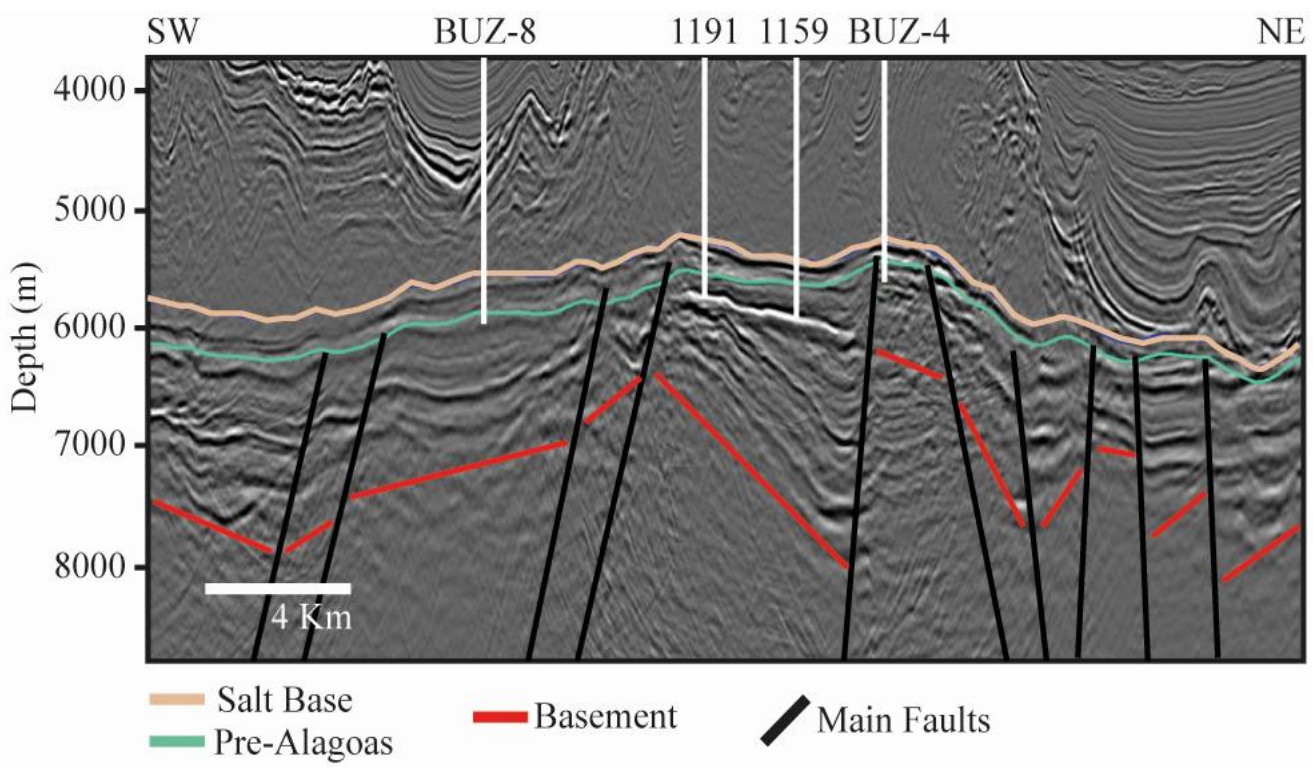

Figure 3: Interpreted seismic horizons on arbitrary line 1 (AB1). 


\section{Results and Discussion}

Two seismic patterns were identified in the study area: build-up and aggradational/progradational carbonate platforms. Their characteristics related to the preconditioned seismic data as well as for the generated attributes used for classification are presented in Figure 4.

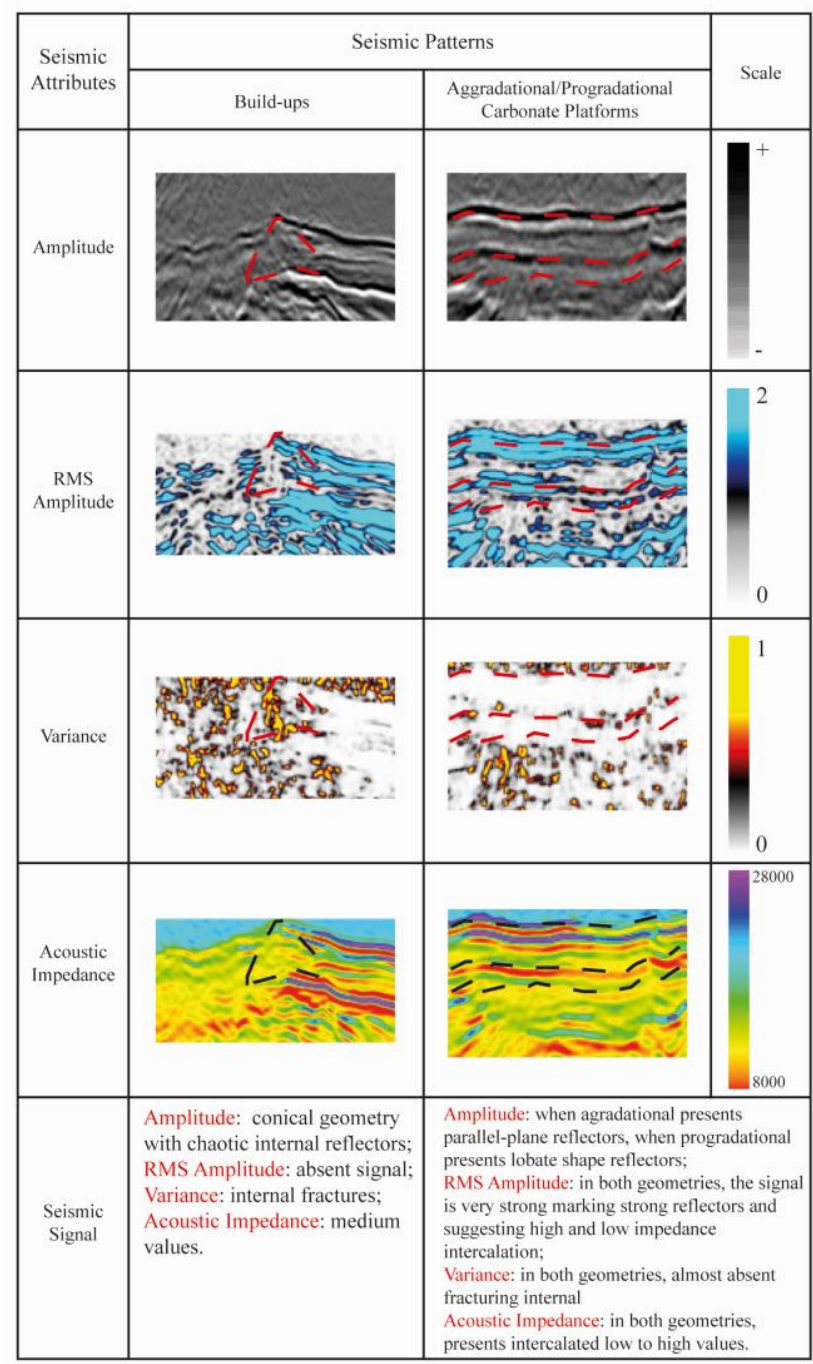

Figure 4: Identified seismic patterns in the Buzios Field and their characteristics related to each of the seismic attributes used in the unsupervised seismic facies classification.

The evaluation of the identified seismic patterns and the seismic facies classification results are represented as seismic sections in Figure 5 and Figure 6 and in map view, projected over the salt base horizon in Figure 7 .

Aggradational/progradational carbonate platform patterns are the most abundant in the Buzios Field. They are distributed throughout all the flat structural highs and lows and are associated with the plane-parallel intercalation of the seismic facies 1,4 and 5 . We can infer that the predominant facies associated with these patterns are grainstones and packstones in the structural highs and pelitic and reworked carbonate sediments at the structural lows.

Seismic patterns associated with build-ups are less abundant in the study area and are mainly located near the main structural high, where the wells were drilled, near the fault zones or in local highs in the southern areas. These features are associated with the chaotic intercalation of the seismic facies 2 and 3 . It is expected that stromatolite/shrub facies and their reworked facies are more predominant in this pattern and that its origin is related to hydrothermal activity (Wright and Barnett, 2015; Wright and Tosca, 2016). Due to this fact, it is possible that these facies can eventually intercalate with volcanic rocks. Also, it is important to note that since the build-up seismic pattern is associated to chaotic seismic signal it can be mistaken with noise in poorly illuminated areas, thus its occurrence in the Buzios Field area can be overestimated. The average proportion maps of build-up and aggradational/progradational seismic facies are shown, respectively, in Figure 8 and Figure 9.

In western area of the Buzios Field, 12 wells are located where the occurrence is mainly carbonate platforms and only 4 wells are in areas were build-ups prevail.

A zonation map of the area was built, considering the most probable seismic attribute classification facies according to the probability maps (Figure 10). Again, we observed that most of the wells were drilled in carbonate platform zones.

Several areas that represent potential targets for new drilling can be observed in structural highs in the eastern part. However, the abundance of build-ups could represent different reservoir behavior regarding facies, porosity and permeability heterogeneity, and anisotropy.

\section{Conclusions}

The use of unsupervised neural network as an advanced technique for the facies classification in the Barra Velha formation proved to be very efficient. Build-ups and carbonate platform seismic patterns were identified and zoned in the study area within the Buzios Field. The selected attributes for neural network seismic facies classification were: (a) rms amplitude, which presented an absent signal for build-up pattern and highlighted strong reflectors for carbonate platform pattern, (b) variance, which showed internal fracturing for build-up pattern and almost absent signal for carbonate platform pattern, and (c) acoustic impedance, which presented medium values for build-up pattern and intercalation of high and low values for carbonate platform pattern. All these identified attribute features coupled with the unsupervised seismic facies classification results allowed the zoning of seismic patterns throughout the area and assisted the construction of a better geological understanding of facies distribution. Most of build-up patterns occur on the faulted zones of structural highs suggesting that is origin is intrinsically connected to faulting. Finally, seismic attribute classification facies probability map coupled with seismic pattern zonation map allowed the determination that 4 wells were drilled in areas with build-up seismic pattern predominance and 12 wells were drilled in areas where the carbonate platform seismic patterns prevail. 


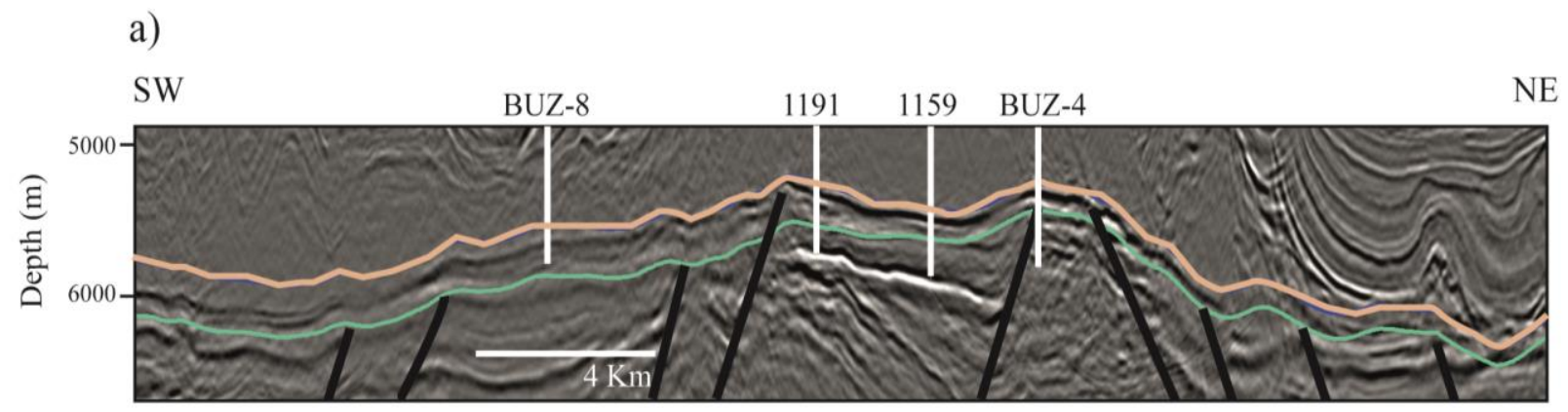

b)
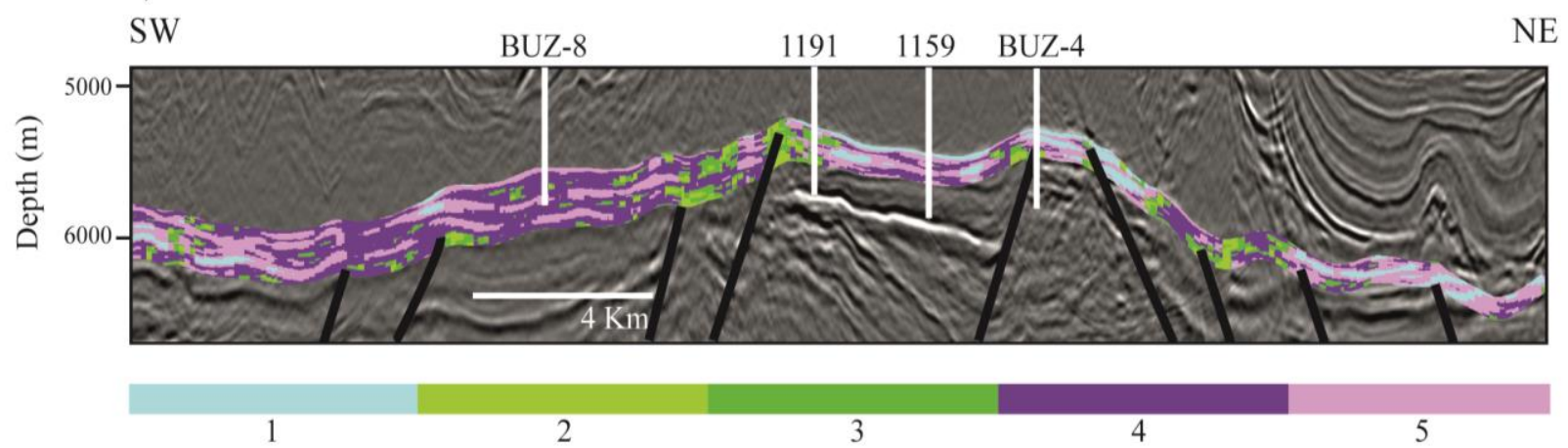

_ Upper Aptian (Base Salt) _ Lower Aptian (Pré-Alagoas) _ Main Faulting

Figure 5: Preconditioned seismic (a) and seismic facies classification results (b) represented in the arbitrary line 1 (AB1).

a)

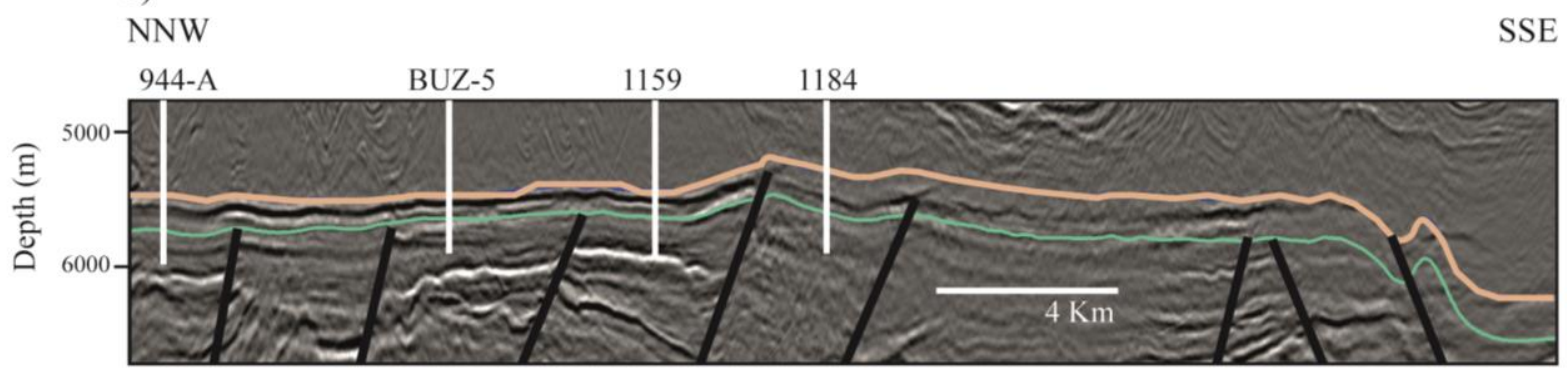

b)

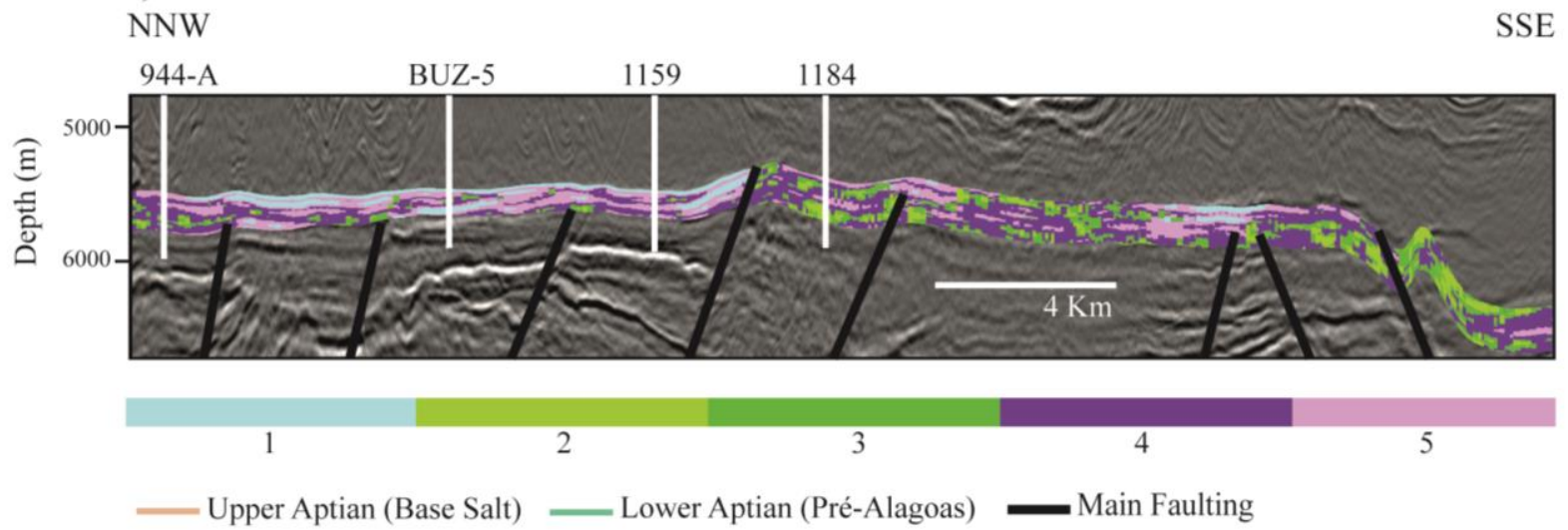

Figure 6: Preconditioned seismic (a) and seismic facies classification results (b) represented in the arbitrary line 2 (AB2). 


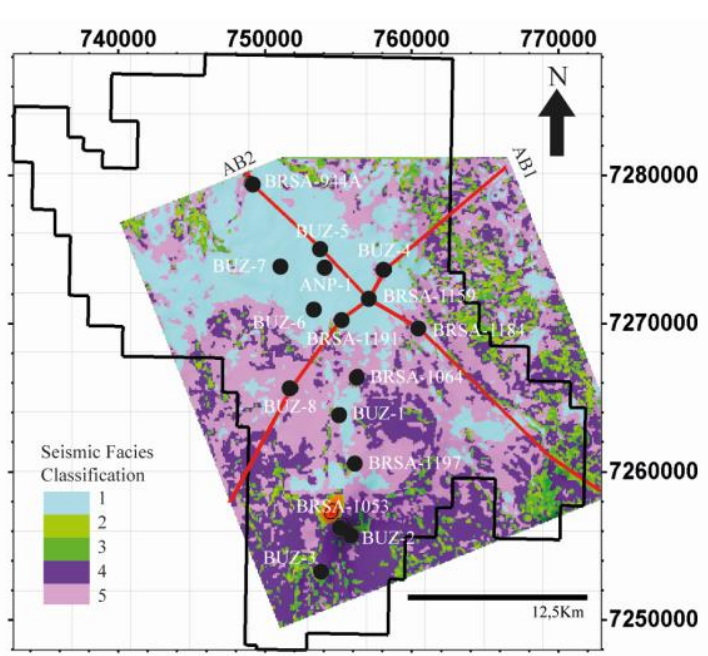

Figure 7: Seismic facies classification results represented in map view over the base of the salt (Barra Velha formation top).

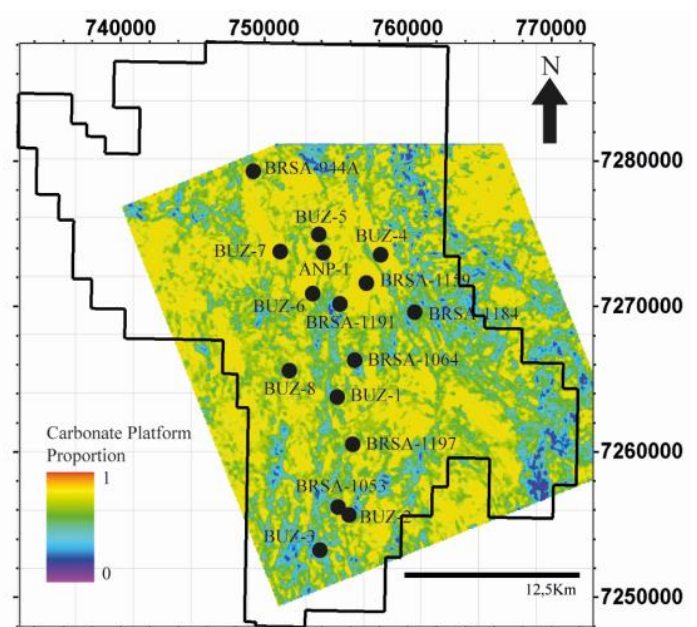

Figure 8: Carbonate platform probability map obtained from seismic facies classification.

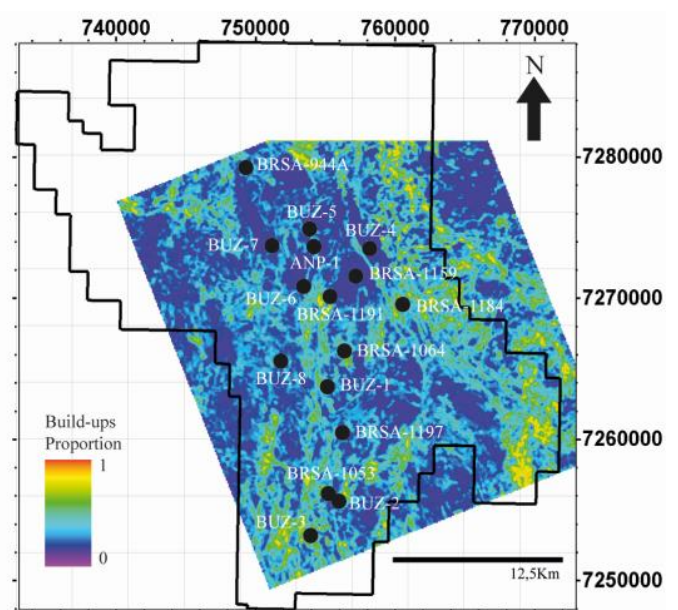

Figure 9: Build-ups probability map obtained from seismic facies classification.

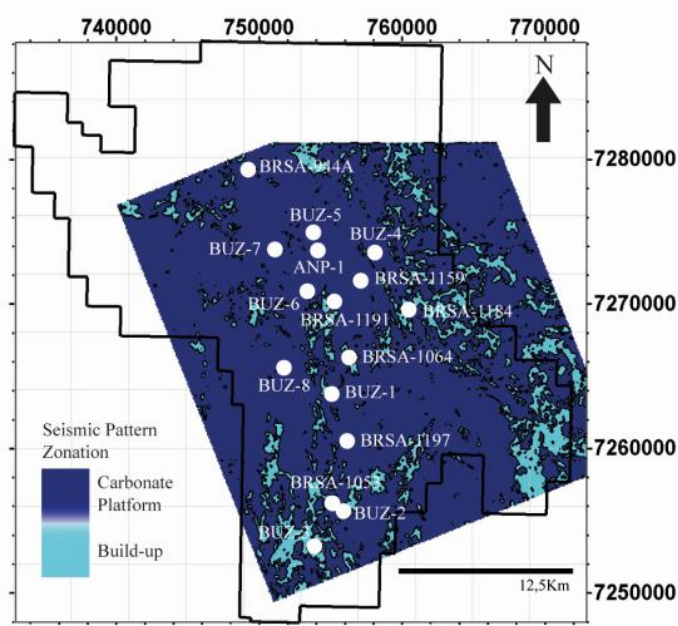

Figure 10: Seismic pattern zonation map built from the most probable seismic facies classification.

\section{Acknowledgments}

The authors thank the Agência Nacional do Pétroleo, Gás Natural e Biocombustível (ANP) for providing the data used in this work, Schlumberger for providing the licenses for Petrel and Techlog softwares, and Emerson-Paradigm for providing the license for EPOS.

\section{References}

Barclay, F., K. B. Rasmussen, A. Cooke, D. Cooke, D. Salter, D. Lowden, S. Pickering, A. Rasmussen, and R. Roberts, 2008, Seismic Inversion: Reading Between the Lines: Oilfield Review, p. 42-63.

Basha, S. K., A. Kumar, J. K. Borgohain, R. Shaw, M. Gupta, and S. Singh, 2012, Rock physics modelling and simultaneous inversion for heavy oil reservoirs: A case study in Western India: First Break, v. 30, no. 5, p. 69-75.

Bemmel, P. P. Van, and R. E. F. Pepper, 2000, Seismic signal processing method and apparatus for generating a cube of variance values, 6,151,555: United States of America, United States, p. 50.

Boyd, A., A. Souza, G. Carneiro, V. Machado, W. Trevizan, B. Coutinho, P. Netto, R. Azeredo, R. Polinski, and A. Bertolini, 2015, Presalt Carbonate Evaluation for Santos Basin, Offshore Brazil: 577 p.

Brown Jr., R. E., and W. L. Fisher, 1977, Seismic stratigraphy interpretation of depositional surfaces: examples from Brazilian rift and pull-apart basins, in C. E. Payton, ed., Seismic Stratigraphy Applications to Hydrocarbon Exploration: Oklahoma, American Association of Petroleum Geologists, p. 213-248.

Bruhn, C. H. L., A. C. C. Pinto, P. R. S. Johann, C. C. M. Branco, and M. C. Salomão, 2017, Campos and Santos Basins: 40 Years of Reservoir Characterization and Management of Shallow- to Ultra-Deep Water , Post- and Pre-Salt Reservoirs Historical Overview and Future Challenges, in OTC Brasil: p. 1-24, doi:10.4043/28159-MS. 
Buckley, J. P., D. Bosence, and C. Elders, 2015, Tectonic setting and stratigraphic architecture of an Early Cretaceous lacustrine carbonate platform, Sugar Loaf High, Santos Basin, Brazil: Geological Society, London, Special Publications, v. 418, no. 1, p. 175191, doi:10.1144/SP418.13.

Dai, J., D. Shelander, G. Bunge, N. Banik, and N. Dutta, 2011, Seismic Detection and Quantification of Gas Hydrates in Northern Gulf of Mexico: Proceedings of the 7th International Conference on Gas Hydrates (ICGH 2011), Edinburgh, Scotland, United Kingdom, July 17-21, 2011, no. 1.

Du, K., and M. N. S. Swamy, 2014, Neural Networks and Statistical Learning: London, Springer London, 824 p., doi:10.1007/978-1-4471-5571-3.

Della Fávera, J. C., 2001, Fundamentos da Estratigrafia Moderna: Rio de Janeiro, EdUERJ, 264 p.

Ferreira, D. J. A., W. M. Lupinacci, I. D. A. Neves, J. Paulo, R. Zambrini, L. Ferrari, L. Antonio, and P. Gamboa, 2019, Unsupervised seismic facies classi fi cation applied to a presalt carbonate reservoir , Santos Basin, offshore Brazil: v. 2, p. 1-16, doi:10.1306/10261818055.

Fornero, S. A., G. M. Marins, J. T. Lobo, A. Fernando, M. Freire, and E. F. De Lima, 2018, Characterization of subaerial volcanic facies using acoustic image logs: Lithofacies and log-facies of a lava-flow deposit in the Brazilian pre-salt, deepwater of Santos Basin: Marine and Petroleum Geology, doi:10.1016/j.marpetgeo.2018.09.029.

Hale, D., 2009, Structure-oriented smoothing and semblance: CWP Report, v. 635, p. 261-270.

Jesus, C., M. O. Azul, W. Lupinacci, and L. Machado, 2017, Mapping of carbonate mounds in the Brazilian presalt zone, in SEG Technical Program Expanded Abstracts 2017: Society of Exploration Geophysicists, p. 3298-3303, doi:10.1190/segam2017-17789870.1.

Johann, P. R., A. F. Martini, A. Maul, and J. P. P. Nunes, 2012, Reservoir Geophysics in Brazilian Pre-Salt Oilfields, in Offshore Technology Conference: Offshore Technology Conference, p. 1-10, doi:10.4043/23681-MS.

Kattah, S., and Y. Balabekov, 2015, Seismic facies/geometries of the pre-salt limestone units and newly-identified exploration trends within the Santos and Campos basins, Brazil, in 14th International Congress of the Brazilian Geophysical Society \& EXPOGEF, Rio de Janeiro, Brazil, 3-6 August 2015: Brazilian Geophysical Society, p. 288-293, doi:10.1190/sbgf2015-057.

McCulloch, W. S., and W. Pitts, 1943, A logical calculus of the ideas immanent in nervous activity: The Bulletin of Mathematical Biophysics, v. 5, no. 4, p. 115-133, doi:10.1007/BF02478259.

Moreira, J. L. P., C. V. Madeira, J. A. Gil, and M. A. P. Pinheiro, 2007, Bacia de Santos: Boletim de Geociencias da Petrobras, v. 15, no. 2, p. 531-549.

Muniz, M. C., and D. W. J. Bosence, 2015, Pre-salt microbialites from the Campos Basin (offshore
Brazil): image log facies, facies model and cyclicity in lacustrine carbonates: Geological Society, London, Special Publications, v. 418, no. 1, p. 221242, doi:10.1144/SP418.10.

Rezende, M. F., and M. C. Pope, 2015, Importance of depositional texture in pore characterization of subsalt microbialite carbonates, offshore Brazil: Geological Society, London, Special Publications, v. 418, no. 1, p. 193-207, doi:10.1144/SP418.2.

Russell, S. J., and P. Norvig (eds.), 2010, Artificial Intelligence: A Modern Approach: New Jersey, Pearson, $1095 \mathrm{p}$.

Saller, A., S. Rushton, L. Buambua, K. Inman, R. McNeil, and J. A. D. T. Dickson, 2016, Presalt stratigraphy and depositional systems in the Kwanza Basin, offshore Angola: AAPG Bulletin, v. 100, no. 7, p. 1135-1164, doi:10.1306/02111615216.

Szatmari, P., and E. J. Milani, 2016, Tectonic control of the oil-rich large igneous-carbonate-salt province of the South Atlantic rift: Marine and Petroleum Geology, v. 77, p. 567-596, doi:10.1016/j.marpetgeo.2016.06.004.

Taner, M. T., F. Koehler, and R. E. Sheriff, 1979, Complex seismic trace analysis: Geophysics, v. 44, no. 6, p. 1041-1063, doi:10.1190/1.1440994.

Terra, J. G. S. et al., 2010, Classificações Clássicas De Rochas Carbonáticas: B. Geoci. Petrobras, Rio de Janeiro, v. 18, no. 1, p. 9-29.

Wright, V. P., 2012, Lacustrine carbonates in rift settings: the interaction of volcanic and microbial processes on carbonate deposition: Geological Society, London, Special Publications, v. 370, no. 1, p. 3947, doi:10.1144/SP370.2.

Wright, V. P., and A. J. Barnett, 2015, An abiotic model for the development of textures in some South Atlantic early Cretaceous lacustrine carbonates: Geological Society, London, Special Publications, v. 418, no. 1, p. 209-219, doi:10.1144/SP418.3.

Wright, P., and N. Tosca, 2016, A Geochemical Model for the Formation of the Pre-Salt Reservoirs , Santos Basin, Brazil: Implications for Understanding Reservoir Distribution: AAPG Annual Convention and Ehibition, v. 51304, p. 32. 